\title{
A personagem Éowyn, de O Senhor dos Anéis, sob um viés da crítica literária feminista e dos Estudos da Tradução
}

\section{Lord of the Ring's character, Éowyn, through the feminist literary critic and the study of adaptation}

Laura Cristina de Souza Zanetti*

Vera Helena Gomes Wielewicki*

" Graduanda da Universidade Estadual de Maringá. E-mail: Iczanetti@outlook.com

* Professora Doutora, colaboradora no Programa de Pós-graduação em Letras da Universidade Estadual de Maringá. E-mail: vhgwielewicki@gmail.com

TradTerm, São Paulo, v.38, fevereiro/2021, p. 252-271

Número Especial - III JOTA 
Resumo: As mulheres integrantes da sociedade nórdica do século $X$ foram, algumas vezes, retratadas como guerreiras, além poderem assumir o papel do marido quando este não estivesse disponível. Diante disso, buscou-se analisar uma possível semelhança entre a mulher nórdica e a personagem Éowyn do romance de J.R.R. Tolkien, O Senhor dos Anéis, publicado entre 1954-1955. Em seguida, pretendeu-se analisar a maneira como a personagem foi ressignificada na adaptação cinematográfica de Peter Jackson de 0 Senhor dos Anéis: As Duas Torres (2002) e 0 Senhor dos Anéis: O Retorno do Rei (2003), por meio da teoria de Linda Hutcheon (2006). A teoria de Kate Millet (1970) embasou o estudo e auxiliou na conclusão de que Éowyn desafia os padrões de personagens femininas de sua época e enfrenta 0 necessário para realizar seu desejo. Éowyn se destaca dentro da narrativa com tamanha intensidade que foi representada, na adaptação cinematográfica, sem grandes mudanças. Finalmente, esta pesquisa proporciona visibilidade a uma personagem feminina que se diferencia por conta de suas atitudes de resistência e contribui para a construção de personagens femininas que quebram estereótipos de representação da mulher.

Palavras-chave: Adaptação cinematográfica; Crítica literária feminista; Mulher nórdica; O Senhor dos Anéis de Tolkien; O Senhor dos Anéis de Peter Jackson.

Abstract: The women who were part of the Nordic society, during the tenth century, used to be at times pictured as warriors and could even take their husbands' place when they were not available. In view of this, the aim is to analyze the influence of the Nordic woman in Éowyn, the character from J.R.R. Tolkien's Lord of the Rings, published between 1954 and1955. Subsequently, the objective was to observe the way Éowyn's characteristics were resignified in the cinematographic adaptation by Peter Jackson, Lord of the Rings: The Two Towers (2002) and Lord of the Rings: The Return of the King (2003), based on Linda Hutcheon's (2006) theory. Kate Millet's (1970) theory was used to support this literary study and the conclusion was that Éowyn challenges the stereotype of feminine characters from that time, since she desires to be something that society does not expect her to be, and she faces everything to achieve it. Éowyn is so noteworthy in the narrative that it resulted in her being adapted to the movie without meaningful changes. Finally, this article provides visibility to a feminine character that differs because of the attitudes of resistance and contributes to the creations of feminine characters that break the stereotype of woman's representation.

Keywords: Cinematographic adaptation; Feminist literary critic; Nordic woman; The Lord of the Rings by J.R.R. Tolkien, The Lord of the Rings by Peter Jackson.

TradTerm, São Paulo, v.38, fevereiro/2021, p. 252-271

Número Especial - III JOTA

www.revistas.usp.br/tradterm 


\section{Estudos sobre a mulher nórdica, a crítica literária feminista de Millet (1970) e a Teoria da Adaptação de Hutcheon (2006)}

A mulher esteve em posição inferior ao homem desde tempos imemoriais, a ponto de uma cultura se criar em torno dos estereótipos femininos e masculinos, devido à política sexual advinda do patriarcado, como explicado por Kate Millet (1970: 25). No século X, por exemplo, existe a possibilidade de a estrutura da Escandinávia pré-viking ter sido baseada na Inglaterra Anglo-Saxônica e na antiga Irlanda, cujos reinos eram governados por reis, duques ou líderes similares. Dessa maneira, a crença que se tinha nos séculos XIX e XX de uma sociedade igualitária é refutada, uma vez que a sociedade era hierárquica (BRINK; PRICE, 2008: 40-47).

A chave para ascensão social nessa época em que havia uma hierarquia a se cumprir era, então, o casamento, podendo ocorrer inclusive entre parentes de famílias vikings, caso fossem nobres, como exposto por Philippe Aries e Georges Duby (1995: 425). As mulheres não tinham direitos, eram subordinadas aos homens e, portanto, suas possibilidades de alcançar qualquer independência e controle econômico e político de suas vidas era quase nulo. Quase, pois algumas mulheres conseguiram alcançar influência considerável através de seus maridos e até após a morte destes (BRINK e PRICE, 2008: 41).

Algumas brechas contidas no casamento, como o concubinato, se agravavam por conta da possibilidade de as duas partes envolvidas terem liberdade de agir como quisessem caso houvesse um desacordo. Isso fez com que várias mulheres conseguissem ir atrás de vingança, pudessem ameaçar seus maridos e até conseguir papel em batalhas, como escudeiras, atuando sempre na defesa armada, mas conseguindo, por outro lado, afastar-se da função de cuidadora da casa, da família e dos feridos. Todavia, o casamento ainda era o tipo de relação que tornava as alianças entre famílias mais fortes (BRINK e PRICE, 2008: 44-45) e (Faur, 2007: 34).

Apesar de os casamentos serem consumados, em sua maior parte, por conta de alianças políticas, as mulheres nem sempre eram obrigadas a casarTradTerm, São Paulo, v.38, fevereiro/2021, p. 252-271

Número Especial - III JOTA

www.revistas.usp.br/tradterm 
se, caso não desejassem, inclusive por serem vistas como autoras do desejo passional e da busca por amor. Também poderiam divorciar-se de seus maridos, inclusive por impotência sexual deles, além de sua virgindade, ou a falta dela, não influenciar no matrimônio. Por outro lado, se fossem consideradas estéreis eram vistas como amaldiçoadas pelos deuses, embora as mulheres tivessem liberdade para se relacionar amorosamente com pessoas do mesmo sexo (BRINK; PRICE, 2008: 46) e (ARIES; DUBY: 471; 525).

Nota-se que já no século $X$ havia estereótipos com relação ao comportamento e deveres de cada sexo. Millet (1970: 23-24) pontua que 0 domínio sexual é provavelmente a ideologia mais persuasiva da cultura humana, que, além disso, provê o conceito fundamental de poder, uma vez que o poder existente na sociedade, incluindo a força coerciva da polícia, está inteiramente em mãos masculinas. A autora alega que esta visão se torna perceptiva quando a divindade é masculina, a ética, os valores, a filosofia e até a arte são de criação masculina.

A autora explica que a política sexual obtém consentimento devido a uma 'socialização' de ambos os sexos para uma sociedade patriarcal com base no temperamento (componente psicológico), no papel (componente sociológico) e no status (componente político) de cada um. 0 status, por exemplo, é uma maneira persuasiva de preconceito que garante a superioridade masculina sobre a feminina. Já o temperamento envolve a formação da personalidade humana por meio de estereótipos da categoria sexual, baseada nas necessidades do grupo dominante e ditadas pelo que os membros apreciam em si mesmos ou acham conveniente nos subordinados. Daí surge, então, a visão de que o homem é agressivo, inteligente, forte e eficaz e a mulher é passiva, ignorante, submissa e ineficaz. Por último, o papel dos sexos, que determina um elaborado código de conduta, gestos e atitude para cada um dos sexos, sendo o serviço doméstico e o cuidado da família às mulheres e o resto das conquistas, interesses e ambições humanas aos homens (MILLET 1970: 26).

As distinções de temperamento criadas pelo patriarcado não são originárias da natureza humana, e são ainda menos as de status e o papel dos sexos. Um exemplo disso é o encorajamento da força masculina através da TradTerm, São Paulo, v.38, fevereiro/2021, p. 252-271

Número Especial - III JOTA www.revistas.usp.br/tradterm 
musculatura, característica comum entre os mamíferos. Apesar de achar que esta não é ainda uma categoria adequada para basear as relações políticas da civilização, Millet (1970: 27) aponta que a civilização sempre foi capaz de substituir métodos como técnica e conhecimento por força física, mesmo sabendo que ela não era mais necessária.

A estudiosa assevera que, por conta desse tipo dessa diferenciação de temperamento, status e papel, a mulher e o homem adquiriram dois tipos de cultura completamente distintos, assim como as experiências de vida, o que Millet (1970: 30-31) acredita ser crucial, por desde a infância existir um padrão de comportamento e pensamento que as crianças devem seguir, de acordo com seu sexo. Na adolescência, esse padrão se torna mais intenso até se solidificar ao atingir a maturidade. Portanto, a infância é a fase decisiva para o desenvolvimento dessas diferenças de temperamento entre os sexos, uma vez que é formada por um ciclo que perpetua e preenche esse tipo de pensamento.

0 fato de cada grupo possuir uma personalidade circunscrita, mas complementar, junto ao alcance de atividades, fica em segundo plano quando o foco é posto no fato de cada um representar uma divisão de poder. 0 chefe, na sociedade patriarcal, é o homem; portanto, ele detém a maior, se não toda, parte do poder. Para Millet, uma vez que o homem fica com o papel de provedor da família, a mulher tende a ser governada pela família, com pouca ou nenhuma relação com o Estado. E caso a mulher domine a casa, esta será vista como provedora de azar ou de pobreza (MILlet 1970: 33). Contudo, Millet (1970: 34) assevera que o patriarcado contemporâneo foi modificado e garante à mulher a proteção de um divórcio, propriedade e cidadania, apesar de ela acreditar que o dia em que os sexos seriam tratados igualmente ainda estava longe.

A distinção feita entre os sexos pode ser observada não somente em acontecimentos da vida real, mas também em diversos tipos de arte, como a literatura e o cinema que, muitas vezes se apropriam de tais fatos para retratar ou até mesmo fazer críticas referentes aos comportamentos sociais. Tanto esse quanto outros tipos de adaptação são vistos por Linda Hutcheon (2006: 22), como essenciais à cultura ocidental a ponto de confirmarem o TradTerm, São Paulo, v.38, fevereiro/2021, p. 252-271

Número Especial - III JOTA

www.revistas.usp.br/tradterm 
insight de Walter Benjamin (1992 APUD HUTCHEON 2006: 22) sobre contar histórias ser sempre a arte de repetir histórias. Contudo, a crítica acadêmica e a resenha jornalística tendem a enxergar as adaptações como secundárias, derivativas, tardias e inferiores justamente pelo fato de nascerem de outras histórias. Essa visão se intensifica com a valorização pós-romântica de criações originais e gênios criativos, fazendo com que a literatura possua um lugar mais alto na hierarquia com relação às adaptações por ser uma forma de arte mais antiga. A autora menciona, ainda, a perspectiva de Robert Stam (2000 APUD HUTCHEON 2006: 24) sobre essa hierarquia envolver o que ele chama de iconofobia (desconfiança quanto ao visual) e logofilia (sacralização da palavra). Inclui-se até mesmo a expectativa contrariada dos fãs das obras adaptadas que esperam fidelidade ao texto estimado por eles, assim como de quem ensina literatura e necessita dessa proximidade para fazê-lo.

Parte do prazer das adaptações advém de uma repetição com variação, da sensação do conhecido mesclada à curiosidade da surpresa, uma vez que lembrança e reconhecimento fazem parte tanto do prazer quanto do risco de ter contato com uma adaptação. Ao juntar a insistência de temas e narrativas à variação do material se criará reproduções diferentes, porém, que não se privam da aura benjaminiana. A repetição, entretanto, não exerce apenas uma função de segurança, não apenas evita riscos como também apela para o financeiro, visto que ao reproduzir algo já bem-sucedido financeiramente evitam-se problemas de ordem econômica (HUTCHEON 2006: 25).

Ao levar em consideração o que foi dito, percebe-se que lidar com adaptações implica entender que as obras virão acompanhadas a todo instante do texto adaptado, mas não resulta em dizer que elas não sejam trabalhos autônomos e não possam ser interpretadas por si mesmas, pois uma adaptação possui uma aura própria, presença e existência no tempo e espaço onde ocorre. Por trás do ato de adaptar há várias intenções presumíveis: desejo de consumo e apagamento da lembrança do texto fonte, objetivo de questioná-lo ou, até mesmo, homenageá-lo (HUTCHEON 2006: 28).

A autora corrobora que, em primeiro lugar, a adaptação seria concebida como uma transposição de uma ou mais obras ao ser vista como entidade ou produto formal. Três podem ser as formas de transpor ou TradTerm, São Paulo, v.38, fevereiro/2021, p. 252-271

Número Especial - III JOTA

www.revistas.usp.br/tradterm 
transcodificar essas obras, segundo Hutcheon (2006: 29): 1) mudança de mídia (de livro para filme); 2) mudança de gênero (romance para épico) ou 3) mudança de foco (recontar a mesma história de um jeito diferente). Por outro lado, como um processo de criação, envolveria tanto uma reinterpretação quanto uma recriação, o que, dependendo da perspectiva, poderia ser chamado de apropriação ou recuperação. Há, ainda, a perspectiva da adaptação como processo de recepção, uma forma de intertextualidade que seria apreciada a partir do contato com a lembrança das obras que ressoam através da repetição com variação. Para que essas formas sejam possíveis de serem reproduzidas, é inevitável haver a discussão sobre uma formalidade específica da arte e também, dos meios. A autora cita uma passagem de Towards a Newer Laocöon, de Clement Greenberg (1940, APUD HUTCHEON 2006), em que ele diz que toda arte tem sua própria formalidade, sua estrutura específica e, dessa maneira, define um foco para estas especificidades por si só, explorando, combinando e multiplicando seus materiais de expressão (HUTCHEON 2006: 62).

Três são os modos de interação da adaptação postulados por Hutcheon (2006: 67-85). O primeiro modo é o "Contar-Mostrar", sendo o mais comum, feito de algo impresso ao encenado. $E$, atualmente, de uma encenação para um material impresso, como aconteceu com os filmes da saga de Star Wars, que ganharam um universo expandido não só com livros, mas também com histórias em quadrinhos, games e até dramas em áudio. Entretanto, ao adaptar um romance, é necessário considerar algumas informações contidas nele e ignorar outras, devido à quantidade de detalhes que ele abrange. Os romances precisam ser dramatizados: descrições, narrações, pensamentos precisam ser transpostos por meio de sons, falas e imagens. Conflitos e ideologias dos personagens precisam se fazer visíveis e audíveis. 0 áudio é tão importante quanto o vídeo, pois consegue reforçar as reações dos personagens além de conectar alguns estados interiores e exteriores de uma maneira mais sutil do que as câmeras. Por outro lado, o visual necessita de cuidado nas escolhas, pois não só a voz, mas a aparência do personagem já foi idealizada. As adaptações poderiam usar o que Charles Sanders Peirce chama de índice e símbolos emblemáticos, que para o cinema seriam os objetos, pessoas e TradTerm, São Paulo, v.38, fevereiro/2021, p. 252-271

Número Especial - III JOTA www.revistas.usp.br/tradterm 
lugares específicos; será inevitável a ênfase e focalização em determinados temas, personagens e enredos específicos determinados pelo adaptador (HUTCHEON, 2006: 67-77).

O outro modo é o "Mostrar-Mostrar", no qual ela explica sobre histórias feitas para um meio de comunicação e adaptadas para outro, como, por exemplo, filmes, muitas vezes já adaptados, que são ressignificados para musicais e depois para filmes novamente. Esse método possibilita duas maneiras de ser produzido: a primeira seria reconhecer o artifício não como um realismo cinematográfico e, sim, como uma autorreflexão; a segunda seria naturalizar esse artifício. Além do cinema, a TV proporcionou adaptações para encenações líricas, e filmes foram adaptados para óperas, uma mistura diferente, em que as convenções naturais do cinema são usadas para traduzir uma forma de arte pouco real. Estes meios mostrados têm em comum o modo de apresentação, mas diferem nas restrições e possibilidade que cada um propõe. Independentemente disso, todas são classificadas como meios de performance (HUTCHEON 2006: 77-82).

Por último, Hutcheon (2006: 82-85) explana o modo 'Interagir-Mostrar ou Contar', em que há interação do público. Esse intercâmbio é mais comum em jogos computadorizados, alguns permitem até mudanças de acordo com a maneira como o jogador lê e interpreta o jogo. Hutcheon (2006: 84) cita, também, um meio um pouco menos interativo, mas ainda sim envolvente, que são as histórias contadas por meio de CDs ou websites, e explica que todos esses meios de adaptação precisam de algumas regras e definições teóricas. Ela menciona Gérard Genette (1979) e a separação que ele em faz entre forma, que seriam a prosa, poesia, imagens, músicas e sons; gênero, romance, peça (tragédia, comédia) e ópera; e modo, narrativo e dramático. Diante disso, ela pontua que os filmes, inicialmente, seguiam os princípios básicos da narrativa em prosa e de peças dramáticas, enquanto desenvolviam suas próprias técnicas e formas, assim como os meios de produção, destruição e consumo. No entanto, os filmes podem encontrar equivalentes cinematográficos e transpor de maneira compreensível o que se passa no pensamento de um personagem ao espectador. No cinema é possível construir correlativos visuais e auditivos para eventos exteriores com as diversas

TradTerm, São Paulo, v.38, fevereiro/2021, p. 252-271

Número Especial - III JOTA

www.revistas.usp.br/tradterm 
técnicas disponíveis que esse meio possui, a exemplo do close, que cria uma intimidade psicológica a ponto de os diretores conseguirem captar ironias interiores e reveladoras.

Diante dos aspectos teóricos abordados até então, buscou-se analisar a influência da mulher nórdica na personagem Éowyn, de O Senhor dos Anéis, originalmente publicado na Inglaterra entre 1954-1955, escrito por J.R.R. Tolkien, além de investigar a trajetória da personagem na adaptação cinematográfica no filme homônimo, 0 Senhor dos Anéis: As Duas Torres (2002) e O Senhor dos Anéis: O Retorno do Rei (2003).

Para que a pesquisa fosse possível foram necessários três eixos principais. 0 primeiro sendo um recorte das partes da narrativa, assim como da adaptação cinematográfica, de 0 Senhor dos Anéis: As Duas Torres (2000A), (2002) e O Senhor dos Anéis: O Retorno do Rei (2000B), (2003) em que Éowyn aparecia. $O$ segundo eixo consistindo em uma análise comparativa das semelhanças da personagem com as mulheres nórdicas. Por último, o terceiro eixo que objetivava uma observação de como Éowyn havia sido ressignificada para a adaptação cinematográfica mencionada.

O papel exercido por Éowyn foi escolhido como objeto de análise deste estudo por se diferenciar dos papéis das demais personagens devido ao seu desejo de se tornar guerreira, que se assemelha à função exercida por algumas mulheres nórdicas em campos de batalha. A personagem se destaca, ainda, por derrotar um importante vilão em uma guerra decisiva na busca pela paz da Terra-Média, o Senhor dos Nazgûl, que não poderia ser morto por um homem. Durante seu percurso na narrativa, Éowyn enfrenta repressão de seu tio Théoden, rei de Rohan e até do homem que amava, Aragorn, Herdeiro de Isildur, por não concordarem com seu objetivo de estar em campo de batalha ao invés de cuidar de seu povo. Por outro lado, na adaptação cinematográfica apesar de ser reprimida por seu tio, deixa de ser por Aragorn e passa a ser por seu irmão, Éomer. A personagem enfrenta as imposições que the foram feitas e parte em busca de seu desejo, embora, após realizá-lo, escolha se casar com Faramir. Essas características encontradas em Éowyn, tais como a vontade de se tornar guerreira, ser independente, forte e a relutância contra os deveres das mulheres da época, além de serem similares aos aspectos da TradTerm, São Paulo, v.38, fevereiro/2021, p. 252-271

Número Especial - III JOTA www.revistas.usp.br/tradterm 
civilização nórdica, são de extrema importância para a construção de futuras personagens femininas que tenham papel e voz mais ativos nas narrativas, tornando-se protagonistas de histórias que as representem como aquilo que elas almejarem ser.

\section{2. Éowyn sob um viés dos estudos de Millet (1970), Hutcheon (2006) e em comparação à mulher nórdica}

Éowyn faz sua primeira aparição em 0 Senhor dos Anéis: As Duas Torres, tanto no livro quanto no filme. A partir de sua descrição como sendo uma mulher possuidora de um belo rosto, longos cabelos cor de rio de ouro, alta, esbelta e "forte como aço, uma filha de reis" (ToLkIEN 2000a: 115), o leitor descobre que ela é sobrinha do rei de Rohan e tinha como maior desejo se tornar guerreira, como se faz notável no trecho "quando ouviu sobre a batalha no Abismo de Helm, sobre a grande matança dos inimigos, e sobre o ataque de Théoden e todos os seus cavaleiros, os olhos dela brilharam" (TolKIEN 2000b: 43). Seu desejo, tal qual o sistema hierárquico que constituía Rohan, se assemelham às características da sociedade viking do século $X$, como as descritas em The Viking World (BRINK, S.; PRICE, N.; 2008: 40-47), por se constituírem de uma hierarquia com reis, chefes, camponeses, entre outros, junto à possibilidade de algumas mulheres estarem em campo de batalha como escudeiras e guerreiras. Por outro lado, durante esse período e por conta dessa hierarquia social existente, as mulheres quase não tinham direitos ou posição econômica suficiente para atuar no campo político e, então, eram subordinadas aos homens.

A ideia de o destino de Éowyn já estar pré-determinado por alguém que não ela mesma, subordinado a um homem do mesmo modo que as mulheres nórdicas, fica clara ao analisar a descrição feita da personagem com ênfase em sua beleza, força e pertencimento à nobreza. 0 fato de ser mulher e filha de reis afastava Éowyn cada vez mais de seu desejo em favor de cuidar do reino e do povo, e por mais que também fosse descrita como sendo tão forte quanto aço há a ideia de submissão, pois Éowyn não conseguia se desprender

TradTerm, São Paulo, v.38, fevereiro/2021, p. 252-271

Número Especial - III JOTA

www.revistas.usp.br/tradterm 
das imposições que the eram feitas por conta de seu sexo e classe social e, consequentemente, se sentia presa. A impotência, e muitas vezes submissão, sentida pela personagem advém do que Kate Millet (1970: 26) entende como uma política sexual consentida, devido à 'socialização' de ambos os sexos para uma sociedade patriarcal baseada no temperamento, status e papel de cada um. Ao perceber que o papel de cada sexo se refere aos gostos, gestos e atitudes que cada um deve ter de acordo com seu sexo, entende-se que, mais uma vez, a repressão do desejo da personagem se dá por conta de ser mulher e de estar inserida numa classe social de nobreza, o que a impede de exercer qualquer função que não seja relacionada à de cuidadora, seja de seu tio, dos visitantes ou de seu povo.

O desejo da personagem era reprimido por seu tio, assim como por outros personagens da narrativa, a exemplo de Aragorn. De acordo com a política sexual consentida, explicada por Millet (1970: 26) essa repressão se encaixa, além do papel dos sexos, no status, também, que diz respeito à maneira persuasiva de preconceito que garante a superioridade masculina sobre a feminina. 0 status de cada sexo se torna evidente quando, na narrativa de Tolkien, Éowyn diz a Aragorn que gostaria de lutar ao lado dele e ele responde:

- Seu dever está com o povo - respondeu ele.

- Já ouvi demais sobre meus deveres - exclamou ela. [...] Já servi a pés vacilantes por muito tempo. Uma vez que eles já não vacilam, ao que parece, não posso eu passar minha vida como desejar?

- Poucos podem fazer isso com honra - respondeu ele. - Mas quanto a você, senhora: não aceitou o encargo de governar seu povo até que o senhor retorne? Se não tivesse sido escolhida, então algum marechal ou capitão teria sido colocado no mesmo lugar, e não poderia fugir da incumbência, estando cansado ou não.

- Serei sempre a escolhida? - disse ela num tom amargo. - Serei sempre deixada para trás quando os Cavaleiros partem, para cuidar da casa, enquanto eles ganham fama, e para preparar-lhes comida, esperando seu regresso?

- Logo pode chegar um tempo - disse ele - em que ninguém retornará. Então haverá necessidade de valor sem fama, pois ninguém se recordará dos feitos realizados na derradeira defesa de suas casas. Apesar disso, os feitos não serão menos corajosos por não serem lembrados.

Ela respondeu: - Todas as suas palavras querem dizer apenas isto: você é uma mulher e seu papel é na casa. Mas, quando os homens estiverem mortos na batalha e com honra, você tem a permissão

TradTerm, São Paulo, v.38, fevereiro/2021, p. 252-271

Número Especial - III JOTA

www.revistas.usp.br/tradterm 
para ser queimada na casa, pois os homens não mais precisarão dela. Mas eu sou da Casa de Eorl, e não uma serviçal. Posso cavalgar e brandir uma espada, e não temo o sofrimento ou a morte (TOLKIEN SARR, 2000b: 44-45).

Aragorn parece não entender e não aceitar que Éowyn tenha capacidade para lutar junto dele, pois the foi imposta outra tarefa, sem antes lhe perguntarem qual era sua vontade, possivelmente por pertencer ao sexo feminino, considerado mais fraco e incapaz de realizar atividades masculinas. A situação se agrava por Éowyn pertencer a uma linhagem nobre e o reino ficar sob sua responsabilidade caso o rei não esteja. É provável que se Éowyn fosse apenas uma camponesa, a opressão de seu desejo não acontecesse de maneira tão acentuada, pois seria considerada alguém menos importante. Em contrapartida, na adaptação Aragorn foi ressignificado como sendo muito mais compreensivo no filme do que realmente era na narrativa de Tolkien, como se observa no diálogo abaixo:

- Você é habilidosa com uma espada.

- As mulheres daqui aprenderam há tempos. A espada mata até quem não tem uma e eu não temo a morte ou o sofrimento.

- O que você teme, minha senhora?

- Uma gaiola. Ficar atrás de grades até que o hábito ou a velhice as aceitem, e a oportunidade de grandes feitos esteja além da lembrança e desejo.

- Você é uma filha de reis, uma guerreira de Rohan. Não creio que este seja seu destino (JACKSON, 1h 09min 36seg, 2002).

No diálogo adaptado, Aragorn deixa de repreender e oprimir os desejos de Éowyn e tenta, no mínimo, entendê-la, visto não haver questionamento por parte dele como acontece na narrativa de Tolkien, além de ele parecer acreditar que o papel dela não é apenas o de cuidadora e não tentar provar uma superioridade masculina. Tais mudanças são chamadas por Linda Hutcheon (2006: 29) de mudanças de foco ou de contexto, visto que o personagem passou por um processo de apropriação para a adaptação cinematográfica, para se portar sob um ponto de vista diferente, aproximando-o do público por torná-lo alguém que merecesse ser admirado. Esse processo de apropriação é considerado comum pela teórica, pois ela pontua que as adaptações têm sua própria aura e são únicas no local em que

TradTerm, São Paulo, v.38, fevereiro/2021, p. 252-271

Número Especial - III JOTA

www.revistas.usp.br/tradterm 
se inserem, por serem uma repetição sem replicação.

Ao considerar a época em que Tolkien escreveu a narrativa, entende-se que seria comum Aragorn e Théoden oprimirem Éowyn por desejar ser uma guerreira, por ela ser uma mulher nobre que pretendia exercer um papel destinado apenas aos homens. Por outro lado, a adaptação cinematográfica é do ano de 2001, já tendo sido influenciada pelo pensamento feminista, pela luta por direitos iguais entre homens e mulheres há algum tempo. Dessa maneira, interpretar o personagem como foi feito, além de torná-lo acessível e o aproximar do espectador também facilitou sua comercialização, algo que, ainda de acordo com Hutcheon (2006: 25-28), são mudanças feitas em benefício da obra, muitas vezes aprovadas pelos próprios autores de obras que estão sendo adaptadas. Contudo, na adaptação, o foco de opressor sai de Aragorn, que se torna mais herói do que antes na narrativa, e passa para Éomer, irmão de Éowyn, quando ele diz à irmã que ela não deveria encorajar Merry, o hobbit, a lutar na batalha final, pois ele era pequeno demais para isso e a guerra era feita apenas para homens. É possível que, por Éomer ser um personagem secundário e com menor visibilidade, essa mudança tenha sido feita para não comprometer a visão de herói que Aragorn carrega e, assim, não o afastar dos espectadores e, consequentemente, não prejudicar a comercialização do filme.

Independentemente das opressões sofridas, Éowyn também encontrou sua maneira de resistir ao que the era imposto quando se disfarçou de guerreiro, sob o pseudônimo de Dernhelm, e partiu para o campo de batalha. 0 interessante do disfarce de Éowyn, é que, na narrativa de Tolkien, o leitor só descobre que ela é o cavaleiro disfarçado quando ela se vê de frente com o Senhor dos Nazgûl, que matou Théoden, e não poderia ser morto por nenhum homem e, então, luta com ele, o matando no final, como mostra o excerto abaixo:

Uma espada tiniu ao ser sacada.

- Faça o que quiser; vou impedi-lo, se conseguir.

- Impedir-me? Tu és tolo. Nenhum homem mortal pode me impedir!

[...] Parecia que Dernhelm estava rindo, e sua voz era cristalina como aço. - Mas não sou nenhum homem mortal! Você está olhando

TradTerm, São Paulo, v.38, fevereiro/2021, p. 252-271

Número Especial - III JOTA

www.revistas.usp.br/tradterm 
para uma mulher. Sou Éowyn, filha de Éomund. Você está se interpondo entre mim e meu senhor, que também é meu parente. Suma daqui, se não for imortal! Pois seja vivo ou morto-vivo obscuro, vou golpeá-lo se tocar nele (TOLKIEN 2000b: 107).

Presume-se que a resistência da personagem seja um dos motivos pelos quais ela foi adaptada para a versão cinematográfica praticamente sem alterações. Contudo, pode-se observar, claramente, nas falas acima os sentimentos de Éowyn com relação ao seu desejo e a reação dos demais quando ela os expõe, o que é visto por Hutcheon (2006: 67-77) como tão necessário quando a imagem, pois o áudio consegue reforçar as reações dos personagens além de conectar alguns estados interiores e exteriores de uma maneira mais sutil do que as câmeras.

Nessa mesma cena com o Nazgûl, no filme ficou implícito que Éowyn está disfarçada de Dernhelm quando divide seu cavalo com Merry em direção à batalha, tornando essa passagem, tanto na narrativa quanto na adaptação cinematográfica, de extrema importância para a construção da personagem, que desconstrói o estereótipo de mulher construído até então. Ao derrotar o Senhor dos Nazgûl, Éowyn provou ser mais capaz de estar em campo de batalha do que qualquer outro, e talvez provando ser até mais necessária, pois como o Nazgûl não poderia ser morto por um homem mortal, nem os Rohirrim, nem Aragorn conseguiriam eliminá-lo. Melissa Hatcher (2007: 45) vê na personagem a presença e persistência na luta da mulher de afirmar sua voz, de evitar ser apagada ou esquecida na história, assim como na vida, pois quando ela percebeu que tentar conversar e expor suas opiniões não a levariam onde ela desejava, enfrentou todas as imposições que the foram feitas para estar onde almejava. Apesar de conseguir se impor e impor seus desejos, Éowyn precisou se disfarçar de cavaleiro para conseguir chegar ao campo de batalha e alcançar seu objetivo, o que na visão de Simone de Beauvoir (1949: 15), seria aceitar a mulher como o Outro, como inferior, pois se ela estivesse sem disfarce provavelmente teria sido impedida, enquanto ao se portar como homem ninguém se importou com sua presença naquele contexto, uma vez que é comum aos homens realizar esse tipo de tarefa. 0 disfarce não diminui o valor e a coragem da personagem, pelo contrário,

TradTerm, São Paulo, v.38, fevereiro/2021, p. 252-271

Número Especial - III JOTA

www.revistas.usp.br/tradterm 
mostra a importância e a necessidade de se lutar contra o papel, status e temperamento dos sexos para que futuramente não haja necessidade de se portar como o Outro em prol de realizar seus desejos.

Éowyn fere o braço ao matar o Nazgûl e é levada às Casas de Cura, em Gondor, junto de Faramir e Merry. Seu estado era grave por conta do ferimento, o que fez com que Aragorn a visse como fraca, ignorando o fato de que sem ela o Senhor dos Nazgûl provavelmente estaria vivo. Gandalf parece ser o único indivíduo do sexo masculino a reconhecer a capacidade de Éowyn, pois ele responde a Aragorn: "você tinha cavalos, e ação armada, e campos livres; mas ela, nascida com o corpo de uma donzela, tinha um espírito e uma coragem no mínimo à altura dos seus" (TOLKIEN 2000b: 134).

Enquanto Gandalf consegue enxergar Éowyn como ela gostaria que os demais a enxergassem, Aragorn sente apenas pena, inclusive do amor que ela sentia por ele e o qual ele não era capaz de retribuir. Essa fragilidade que Aragorn estereotipa em Éowyn está relacionada ao temperamento de cada sexo, explicado por Millet (1970: 26) como estereótipos baseados nas necessidades do grupo dominante e ditadas pelo que os membros apreciam em si mesmos ou acham conveniente nos subordinados. Seria a partir disso que a visão de submissa, passiva e ineficaz teria sido associada à mulher, e nesse caso, a Éowyn, enquanto a visão de agressividade, força e inteligência ligada ao homem, ou a Aragorn. Sob outra perspectiva há Faramir, que conhece Éowyn durante a estada dos dois nas Casas de Cura e se apaixona à primeira vista. É perceptível que Faramir enxergou Éowyn como igual desde a primeira vez que se viram, ele conseguiu ver nela a grandeza que ela buscava para si mesma, e a ajudou a enxergar isso, por mais que possam ser observadas características dos estereótipos impostos aos sexos em seu discurso, como quando ele diz que Éowyn desejava o amor de Aragorn apenas por conta de sua posição e renome.

A personagem passa por um momento de transição enquanto está nas Casas de Cura, o que é interpretado por Anna Wallace (2011: 37) como sendo um renascimento após uma morte metafórica causada pelo ferimento da batalha e o amor não correspondido por Aragorn. Éowyn buscava glória e reconhecimento ao desejar ser escudeira; é possível inferir, então, que esse TradTerm, São Paulo, v.38, fevereiro/2021, p. 252-271

Número Especial - III JOTA

www.revistas.usp.br/tradterm 
renascimento metafórico tenha the mostrado que a glória e o reconhecimento podem ser alcançados de outras maneiras, sendo uma delas cuidar de quem precisa e espalhar amor em momentos de guerra, visto que a personagem tinha consciência de não ser por falta de capacidade, ou por ser do sexo feminino, que ela não poderia ser uma escudeira. Ainda durante esse momento de transição, Éowyn decide aceitar o pedido de casamento de Faramir, visto por Hatcher (2007: 52) como um ideal moderno de relacionamento, pois para ela os dois exercem o mesmo papel dentro do relacionamento, além de Faramir enxergar Éowyn como ela realmente é, o que the permite ter voz e papel ativo na relação. Por outro lado, Millet acredita que o amor romântico serve para amenizar o patriarcado junto ao casamento, que seria uma maneira de controlar as ações e os papéis das mulheres. Porém, como Éowyn tinha total liberdade para se expressar dentro do relacionamento, e Faramir se apaixonou mesmo sabendo de seus desejos e sabendo quem ela era e queria ser, estima-se que a decisão de Éowyn tenha sido a de se casar por perceber que tinha mais em comum com Faramir do que com Aragorn, além do fato de terem se sentido bem na companhia um do outro enquanto se recuperavam nas Casas de Cura e não por ser um dever da mulher se casar e estabelecer família. A liberdade na escolha de seu parceiro também se assemelha às mulheres nórdicas, como pontuam Brink, Price (2008: 44-45) e Faur (2007: 34), uma vez que elas não eram obrigadas a se casar apenas para assegurar posição social, mas também por amor, pois tinham autonomia para serem responsáveis pelos próprios desejos, do mesmo modo que Éowyn.

Esse contato entre Éowyn e Faramir fica implícito na adaptação cinematográfica, algo visto por Hutcheon (2006: 67-77) como essencial devido à quantidade de detalhes contidos em romances; porém, ela explica que é necessário haver dramatização, que o pensamento e as reações dos personagens sejam audíveis e visíveis. A adaptação retratou a empatia que Faramir e Éowyn sentiram um pelo outro, assim como deixou implícito que se casariam utilizando apenas duas cenas.

TradTerm, São Paulo, v.38, fevereiro/2021, p. 252-271

Número Especial - III JOTA

www.revistas.usp.br/tradterm 


\section{Conclusão}

À guisa de conclusão, o sistema hierárquico no qual Rohan era baseado assemelha-se com o das sociedades nórdicas, pois os dois se constituem de reis, camponeses, chefes, entre outros, além da possibilidade de as mulheres se tornarem guerreiras, assim como era o desejo de Éowyn, e terem a liberdade na escolha de seus maridos por amor e não somente com foco em ascensão social. Por outro lado, é, em partes, por conta do sistema hierárquico no qual Rohan se baseia que Éowyn se sente presa, pois ela vem de linhagem nobre. Sua nobreza e o fato de ser do sexo feminino fazem com que seu desejo de se tornar guerreira seja reprimido por seu tio Théoden, por Aragorn, e, na adaptação cinematográfica, por seu irmão Éomer, pois não era comum mulheres lutarem em batalhas, uma vez que eram consideradas inferiores e ineficazes em atividades que não fossem relacionadas à casa e de cuidadoras.

O pensamento de que cada sexo tem um papel específico, no caso, Éowyn o de cuidadora de seu reino e povo e os homens de guerreiros, é explicado por Kate Millet (1970: 26), assim como o temperamento de cada sexo e o status como sendo uma consequência das sociedades patriarcais e uma forma de inferiorizar os indivíduos para então os controlar. Tal fato é percebido por sempre tentarem lembrar Éowyn de que seu lugar não é e nunca será no campo de batalhas por ser sobrinha de um rei e mulher, além de fazerem com que ela aceite ordens e tarefas de cuidadora durante quase toda a narrativa. Todavia, Éowyn resiste à repressão de seu desejo da melhor maneira que encontra, já que ela se vê suficientemente capacitada para exercer a função de guerreira mesmo que tenha que aceitar sua condição de Outro, termo usado por Simone de Beauvoir (1949: 15), ao se vestir de homem para que possa lutar.

A atitude de Éowyn ao se disfarçar de Dernhelm para lutar foi essencial na restauração da paz na Terra-Média, posto que ela matou o Senhor dos Nazgûl justamente por ser mulher, pois ele não poderia ser morto por nenhum homem mortal. Dessa maneira, por mais que tenha saído ferida, a personagem provou ser mais necessária em campo de batalha do que qualquer

TradTerm, São Paulo, v.38, fevereiro/2021, p. 252-271

Número Especial - III JOTA

www.revistas.usp.br/tradterm 
outro, além de provar resistência e força para enfrentar as imposições que the eram feitas, mesmo que após se recuperar do ferimento desta batalha tenha decidido abandonar o sonho de ser uma guerreira para ajudar a Terra-Média sendo cuidadora e espalhando amor àqueles que necessitavam, além de se apaixonar por Faramir durante sua estadia nas Casas de Cura e acabar se casando com ele.

A transição da personagem pode ser interpretada como um momento de libertação, visto que ela provou sua capacidade e a necessidade de sua presença no campo de batalha, alcançando a glória por seus feitos, além de encontrar em sua relação com Faramir algo puro e sincero, pois ele se apaixonou por ela desde a primeira vez que a viu, sempre respeitando e não oprimindo, diferentemente de quando ela tentou se aproximar de Aragorn, que, além de ser comprometido com Arwen, acreditava que o papel a ser exercido por Éowyn era o de senhora de Rohan e nada mais.

Com relação à adaptação cinematográfica, O Senhor dos Anéis foi adaptado pelo modo Contar-Mostrar, considerado o tipo de adaptação mais comum, feito de algo impresso para o encenado. Houve, portanto, uma transposição, que Linda Hutcheon (2006: 29) chama de mudança de mídia. Nesse tipo de adaptação se faz necessário retirar algumas informações e acrescentar outras, devido ao tamanho das narrativas, que torna difícil sua adaptação para filmes, teatros, entre outros, pela quantidade de detalhes. $\mathrm{Na}$ adaptação de $O$ Senhor dos Anéis, foi observada uma reinterpretação na aparição de Éowyn, mantendo o foco apenas nas cenas mais marcantes para a construção da personagem e excluindo, por exemplo, algumas cenas nas quais Éowyn interage com Faramir. Houve ainda uma omissão na repressão de Aragorn com relação a Éowyn, que passa a agir ainda mais como o herói compreensivo, enquanto cenas em que Théoden expõe a Éowyn que ela não deveria ser guerreira e Éomer lhe diz que a guerra era um lugar apenas para os homens são criadas. Omissões e mudanças são normais em adaptações, por estas serem uma recriação, reinterpretação, possuidoras de uma aura própria e uma existência única, de acordo com Hutcheon (2006: 28). As mudanças feitas em Aragorn para a adaptação cinematográfica foram as chamadas, pela estudiosa, de mudanças de contexto, visto que ele passou por um processo de

TradTerm, São Paulo, v.38, fevereiro/2021, p. 252-271

Número Especial - III JOTA

www.revistas.usp.br/tradterm 
apropriação para o cinema, para se aproximar do público e se tornar alguém que merecesse ser admirado, aumentando, assim, as chances de sucesso e comercialização da adaptação. Talvez por conta da comercialização do filme Éomer e Théoden tenham sofrido a mudança oposta, já que não comprometeriam nesse aspecto, em razão de serem personagens secundários, cuja visibilidade era inferior a de Aragorn. Em contrapartida, especialmente a personagem Éowyn não teve mudanças significativas, em sua personalidade no cinema, ainda que o áudio tenha sido usado a favor de uma ênfase em suas ações e participação. É presumível que isso decorra do fato de ela ser uma personagem que se destaca por conta das características de resistência e por quebrar algumas barreiras impostas a personagens femininas até então. Embora haja interesse comercial por trás, a importância de mulheres como Éowyn, e até mais desenvolvidas, se faz necessária para que muitos outros estereótipos de representação da mulher sejam quebrados.

Nota-se, portanto, que a adaptação cinematográfica do filme em questão faz referências ao texto de partida, embora possa ser entendida como autônoma no tempo e espaço em que existe. Omissões e acréscimos foram feitos de acordo com a interpretação e objetivos daqueles que optaram por ressignificar o texto para outro meio, criando uma aura de surpresa e outra visão de uma obra já existente e conhecida.

Finalmente, Éowyn desafia os padrões que personagens femininas de sua época costumam seguir ao almejar um papel não condizente com o que a sociedade espera que ela exerça, algo que pode ser observado tanto na narrativa de Tolkien quanto na adaptação cinematográfica. Portanto, esta pesquisa proporciona certa visibilidade para uma personagem feminina que se diferencia por conta de suas atitudes de resistência e contribui para a construção de personagens femininas que quebram estereótipos de representação da mulher, além de permitir que haja reflexão acerca dos temas discutidos, podendo ser utilizado, inclusive, ao ensinar literatura no ensino básico com a possibilidade de haver, ainda, um pequeno foco em tradução.

TradTerm, São Paulo, v.38, fevereiro/2021, p. 252-271

Número Especial - III JOTA

www.revistas.usp.br/tradterm 


\section{Referências}

ARIES, P.; Duby, G. História da Vida Privada: do Império Romano ao Ano Mil. Hildegard Feist. São Paulo: Schwarcz, 1995.

Beauvoir, S. O Segundo Sexo. 2.ed. Tradução de Sergio Millet. Rio de Janeiro: Nova Fronteira, 1949.

BRINK, S.; PRICE, N. The Viking World. Nova York: Routledge, 2008.

FAUR, M. Mistérios nórdicos: deuses, runas, magia, rituais. São Paulo: Pensamento, 2007.

HATChER, M. M. Finding Woman's Role in The Lord of the Rings. Mythlore Society, Tennessee, 2007.

HUtCHEON, L. A Theory of Adaptation. New York: Taylor \& Francis, 2006.

Millet, K. Sexual Politics. Nova York: Doubleday, 1970.

O SENHOR DOS ANÉIS: AS DUAS TORRES. Direção de Peter Jackson. Nova Zelândia: New Line Cinema e Wingnut Films Production, 2002. 1 DVD (179 min);

O SENHOR dOS ANÉIS: O RETORNO DO REI. Direção de Peter Jackson. Nova Zelândia: New Line Cinema e Wingnut Films Production, 2003. 1 DVD (201 min);

SCHNEIDER, L. "Contando estórias feministas" e a reconstrução do feminismo recente. Estudos Feministas, Florianópolis, v. 17, p.251-263, janeiroabril, 2009.

TolkIEN, J. R. R. O Senhor dos Anéis: As Duas Torres. Tradução Lenita M. R. Esteves, Almiro Pisetta. São Paulo: Martins Fontes, 2000a.

TolkIEN, J. R. R. O Senhor dos Anéis: O Retorno do Rei. Tradução Lenita M. R. Esteves, Almiro Pisetta. São Paulo: Martins Fontes, 2000b.

Valente, C. Translating Tolkien's Epic: Peter Jackson's Lord of the Rings. Walla Walla: The Intercollegiate Review, 2004.

Wallace, A. A Wild Shieldmaiden of the North: Éowyn of Rohan and Old Norse Literature. Philament Monstrosity, 2011.

Recebido em: 10/02/2020

Aceito em: 03/12/2020

Publicado em fevereiro de 2021

TradTerm, São Paulo, v.38, fevereiro/2021, p. 252-271

Número Especial - III JOTA

www.revistas.usp.br/tradterm 